\title{
PENGARUH OBJEK WISATA WADUK TERHADAP PENDAPATAN PEDAGANG DESA JEULIKAT KECAMATAN BLANG MANGAT KOTA LHOKSEUMAWE
}

\author{
Muhammad Firdaus $^{\mathrm{a} 1}$, Hijri Juliansyah ${ }^{\mathrm{a} 2}$ \\ ${ }^{a}$ Fakultas Ekonomi dan Bisnis Universitas Malikussaleh \\ 1Corresponding author : muhammadfirdausekp@gmail.com \\ 2 hijri@unimal.ac.id
}

\section{A R T I CLE I N F O RMA T I O N}

Keywords:

Attraction, Reservoir, Revenue.

\section{A B S T R A C T}

This study aims to analyze the influence reservoir tourism on the community income of Jeulikat Village, Blang Mangat District, Lhokseumawe City. The study uses primary data collected from 40 respondents. The data analysis method used is a simple linear regression. The results showed that the number of visitors significantly influences the income of the community. It is hoped that the Jeulikat Reservoir tourism can be used as a source of tourist attractions that are able to attract the interest of tourists in Lhokseumawe city.

\section{PENDAHULUAN}

Dimasa sekarang ini kemajuan di bidang pariwisata sangatlah pesat. Industri pariwisata sudah menjadi suatu industri yang sudah berkembang pesat dimasa sekarang ini, hal ini terlihat dari adanya perkembangan suatu daerah dan tingkat daya serap pekerja (Widodo, Y., Fandeli, C., Baiquni, Damanik, 2011). Dari segala jenis dimensi perkembangan industri kepariwisataan diramalkan akan terus berkembang.

Hal ini akan wujud apabila pengambil kebijakan mampu mengembangkan potensi yang terkandung seperti potensi-potensi di tempat wisata. Sektor pariwista mampu mendorong perekonomian suatu daerah sehingga sektor ini dianggap begitu penting. Adapun daerah yang mempunyai tempat wisata tentu akan menghasilkan keuntungan yang cukup besar bagi daerah/tempat tersebut (Gusneli, 2016).

Wisata menunjukkan suatu bentuk nyata atau proses bagi seseorang dalam melakukan perjalanan menuju suatu tempat guna mendapatan suatu kenyamanan dan menikmati keindaahan alam, dimana kegiatan wisata bersifat untuk memperoleh kesenangan untuk sementara waktu setelah melakukan aktivitas kehidupan yang sangat banyak. Dengan melakukan wisata tubuh dan pikiran menjadi segar kembali serta mampu menjalankan pekerjaan seperti biasanya dan mampu menghasilkan ide-ide cemerlang.

Aceh memiliki tempat-tempat wisata yang juga mampu menarik banyak wisatawan. Seperti wisata pantai yang mempesona dan pemandangan sepanjang pegunungan yang mampu membuat hati takjub setiap yang melihatnya. Adanya objek wisata dapat dijadikan sebagai suatu dampak positif bagi daerah dimana objek wisata dapat meningkatkan sumber pendapatan asli daerah.

Dari begitu banyaknya tempat wisata yang berada di Aceh, penulis menfokuskan pada wilayah kota Lhokseumawe, yang mempunyai tempat wisata yang baru yaitu Waduk yang ada di Desa Jeulekat, Kecamatan Blang Mangat, Kota Lhokseumawe.

Meskipun tempat wisata Waduk Jeulikat masih terbilang baru, namun karena berbagai inovasi yang diciptakan oleh para pengelola waduk, setelah membuat tempat wisata ini selalu dikunjungi oleh wisatawan dari waktu ke waktu. .

$$
\text { Wisata waduk Jeulikat di Kota }
$$

Lhokseumawe mulai ramai di kunjungi oleh masyarakat baik masyarakat Kota Lhokseumawe maupun masyarakat luar Kota Lhokseumawe sejak tahun 2015. Fasilitas yang disediakan di Waduk Jelikat berupa pondok-pondok tempat pengunjung 
beristirahat, tersedianya tempat parkir, toilet, serta musalla. Untuk menarik minat pengunjung di wisata waduk Jeulikat juga diciptakan berbagai fasilitas seni berupa lukisan dan ukiran di sekeliling waduk Jeulikat.

Pada dasarnya waduk ini berfungsi sebagai sumber aliran air persawahan di desa jeulekat yang dimanfaatkan pada saat musim kering. Waduk Jeulikat dikelilingi oleh sejumlah bukit yang penuh dengan pohon-pohon dan rumput yang hijau, sehingga pemandangan yang terlihat begitu indah dan menawan. Waduk ini mempunyai satu tangga yang bisa digunakan pengunjung untuk turun dan melihat keindahan waduk ini.

Objek wisata Waduk Jeulikat merupakan objek wisata buatan manusia yang dasarnya merupakan rawa-rawa yang sudah ada dari puluhan tahun yang lalu dan dimanfaatkan oleh petani sebagai tempat penampungan air untuk persawahan yang ada di desa Jeulikat dan sekitarnya. Namun karena adanya inisiatif dari Walikota Lhokseumawe, yaitu Bapak Suaidi Yahya yang bekerja sama dengan masyarakat, sehingga rawa-rawa tersebut disulap menjadi tempat wisata yang ramai dikunjungi dari hari ke hari.

Berikut ini merupakan beberapa data yang diperoleh penulis dari hasil survei lapangan dan penulis sajikan pada tabel dibawah ini.

Tabel 1

Data Pendapatan Pedagang Pada Waduk Jeulikat Kota Lhokseumawe

\begin{tabular}{|l|l|l|l|}
\hline No & Nama & $\begin{array}{l}\text { Pekerjaan } \\
\text { Sebelumnya }\end{array}$ & $\begin{array}{l}\text { Pendapatan } \\
\text { Rata-Rata } \\
\text { perbulan }\end{array}$ \\
\hline 1 & Ismail & Buruh Bangunan & Rp. 6.000.000 \\
\hline 2 & Rijal & Wiraswasta & Rp. 4.000.000 \\
\hline 3 & Salamah & $\begin{array}{l}\text { Pedagang di } \\
\text { Sekolah Dasar (SD) } \\
\text { Jeulikat }\end{array}$ & Rp. 2.000.000 \\
\hline 4 & Ramlah & IRT & Rp. 2.500.000 \\
\hline 5 & Nurlaila & IRT & Rp. 2.000.000 \\
\hline
\end{tabular}

Sumber : Data Primer, 05 November 2017 (diolah)

Dari tabel 1 di atas dapat dilihat bahwa pendapatan yang diterima pedagang Waduk Jeulikat tidaklah sama. Hal ini mungkin dikarenakan barang dagangan mereka pun berbeda, ada pedagang yang hanya berjualan makanan ataupun minuman dalam bentuk instan (seperti snack, minuman berbentuk kemasan yang sudah jadi, atau sejenis lainnya), ada yang menjual jagung bakar atau makanan sejenis lainnya, bahkan ada pula yang serba ada.

Sehingga hal ini menjadi faktor yang membuat pendapatan para pedagang ini berbeda. Jumlah pengunjung paling banyak di hari akhir pekan (sabtu dan minggu) dikarenakan di hari minggu banyak orang-orang yang libur seperti orang-orang yang bekerja pada organisasi pemerintah dan anak anak sekolah sehingga pendapatan pedagang juga lebih meningkat di bandingkan dengan hari-hari biasa.

Tujuan penelitian ini adalah untuk melihat Pengaruh Objek Wisata Waduk Terhadap Pendapatan Masyarakat Desa Jeulikat Kecamatan Blang Mangat Kota Lhokseumawe".

Bagian kedua dari penelitian ini akan membahas tinjauan teoritis, metode penelitian akan dibahas pada bagian ketiga. Kemudian pada bagian ke empat akan dibahas hasil penelitian dan pembahasan. Pada bagian kelima akan membahas kesimpulan dan saran.

\section{TINJAUAN TEORITIS Pendapatan}

Tujuan dijalankannya suatu usaha di bidang perdagangan adalah untuk mengahasilkan sejumlah keuntungan dimana sejumlah keuntungan tersebut bisa dimanfaatkan dalam memenuhi kebutuhan hari-hari maupun sebagai keberlanjutan usahanya tersebut. Pendapatan berupa sejumlah uang yang dihasilkan oleh perusahaan/organisasi dari kegiiatan operasinalnya, pendapatan tersebut umunya diperoleh dari hasil produk yang dijual kepada konsumen (Afifudin, 2016).

Menurut Reksoprayitno (2004) dalam (Ratnasari, 2015) sebagai pendapatan yang disebut juga sebagai revenue memberikan artian sebagai jumlah yang diterima yang diperoleh pada waktu tertentu, dengan demikian dapat disimpulkan bahwa Penerimaan uang adalah sejumlah uang yang dihasilkan oleh kelompok masyarakat dalam kurun waktu yang telah ditentukan sebagai bentuk balas jasa atas barang-barang yang telah di berikan atau didapatkan. 
Menurut (Sukirno, 2006). pendapatan uang adalah jumlah Penerimaan uang yang didapat oleh penduduk atas kerjanya selama satu waktu tertentu, baik dalam harian, mingguan, bulanan atau tahunan. Dan ada beberapa klasifikasi Penerimaan uang yaitu : Pendapatan Pribadi Semua jenis Penerimaan uang yang diperoleh tanpa memberikan sesuatu kegiiatan apapau yang diterima penduduk suatu negara.

\section{Jenis-Jenis Pendapatan}

Secara garis besar, jenis-jenis pendapatan digolongkan menjadi tiga golongan, (Jaya, 2011), yaitu:

a. Gaji dan upah, yaitu imbalan yang dihasilkan setelah menyelesaikan pekerjaan dalam sehari.

b. Pendapatan dari usaha sendiri merupakan nilai total dari hasil produksi yang dikurangi dengan biaya-biaya yang dibayar

c. Pendapatan dari usaha lain, yaitu pendapatan yang didapat tanpa mencurahkan tenaga kerja dan ini merupakan ppendapatan sampingan.

\section{Faktor-Faktor Yang Mempengaruhi Pendapatan}

Berikut ini merupakan beberapa faktor yang dapat mempengaruhi pendapatan masyarakat (Widodo, Y., Fandeli, C., Baiquni, Damanik, \& ., 2011) yaitu:

a. Modal usaha: setiap orang yang memulai usaha memerlukan modal. Pada umumnya, modal yang dikeluarkan di awal juga akan menetukan jumlah pendapatan yang akan diterimanya.

b. Kesempatan kerja yang tersedia: Semakin banyak kesempatan kerja yang diperoleh oleh seseorang, makan akan semakin banyak pula pendapatan yang akan diterimanya.

c. Tingkat Pendidikan: Seseorang yang memiliki tingkat pendidikan yang tinggi pastinya juga akan berpikir tentang usaha yang bisa ia jalani dan menghasilkan pendapatan yang tinggi.
Biasanya, semakin tinggi pendidikan seseorang maka semakin tinggi pula pendapatan yang ia harapkan.

d. Lama usaha: Orang yang dapat mempertahankan usahanya untuk waktu yang lama pasti akan mendapatkan pendaatan yang semakin tinggi.

\section{Objek Wisata \\ Pengertian Wisata}

Wisata adalah suatu perubahan tempat tinggal sementara seseorang diluar tempat tinggalnya karena suatu alasan dan bukan untuk kegiatan yang menghasilkan upah.

Obyek Wisata juga dapat diartikan sebagai tempat yang memiliki sumber daya wisata dapat berupa wisata alam seperti gunung, danau, sungai, pantai, laut, waduk atau berupa objek bangunan seperti museum, benteng, situs peninggalan sejarah, dan lain-lain(Hiariey \& Sahusilawane, 2013).

\section{Fasilitas Objek Wisata}

Menurut (Afifudin, 2016) salah satu hal penting untuk mengembangkan pariwisata adalah melalui fasilitas (kemudahan). Tidak jarang wisatawan berkunjung ke suatu tempat atau daerah atau negara, karena tertarik oleh kemudahankemudahan yang bisa diperoleh melalui fasilitas.

Fasilitas wisata adalah semua fasilitas yang fungsinya dapat memenuhi kebutuhan wisatawan yang tinggal di daerah tujuan wisata yang dikunjunginya, dimana mereka dapat santai menikmati dan berpartisipasi dalam kegiatan yang tersedia di daerah tujuan wisata tersebut(Ratnasari, 2015).

\section{Pariwisata}

\section{Pengertian Pariwisata}

Menurut Soekadijo (2010) pengertian pariwisata adalah segala kegiiatan dalam masyarakat yang berhubungan dengan wisata wan. Pariwisata ini menurut Salah Wahab (dalam Pendit, N.S, 2013) adalah salah satu jenis industri baru yang menghasilkan pertumbuhan ekonomi dengan cepat dalam penyedia lapangan kerja, peningkatan penghasilan, standar hidup serta mensimulasi sektor-sektor produktivitas lainnya. 
Jenis industri baru yang dimaksudkan disini adalah dalam bidang jasa seperti jasa transportasi, jasa akomodasi dan lain-lain, yang mana apabila dikelola dengan professional dan baik dalam akan menghasilkan pencapaian yang ingin dicapai.

\section{Jenis Pariwisata}

Seorang wisatawan mengadakan perjalanan wisata karena didorong oleh berbagai motif yang tercermin dalam berbagai macam jenis pariwisata. Bagi pihak terkait sangat perlu mempelajari motif ini karena berhubungan dengan fasilitas yang perlu disiapkan dan program-program promosinya. Berikut ini beberapa pendapat yang menjelaskan perbedaan jenis pariwisata, yaitu :

1. Pariwisata untuk rekreasi (recreation tourism).

2. Pariwisata untuk olah raga (sport tourism). Jenis ini dibagi dua kategori:

\section{a. Big sport events}

3. Sporting tourisnm of the practitioner

4. Pariwisata untuk usaha dagang (business tourism).

5. Pariwisata untuk berkonvensi (convention tourism).

\section{Wisatawan}

Wisatawan adalah orang-orang yang dapat melakukan kegiatan wisata (UU nomor 10 tahun 2009). Artinya, semua orang yang melakukan perjalanan wisata dinamakan wisatawan. Apapun tujuannya, yang penting perjalanan itu tidak untuk menetap dan bukan mencari nafkah ditempat yang dikunjungi. Adapun beberapa pejelasan tentang wisatawan, diantaranya yaitu:

1. Orang-orang yang melakukan perjalanan untuk bersenang-senang

2. Orang-orang yang melakukan perjalanan untuk pertemuan

3. Orang-orang yang melakukan perjalanan perjalanan dengan maksud bisnis.

\section{Karangka Konseptual}

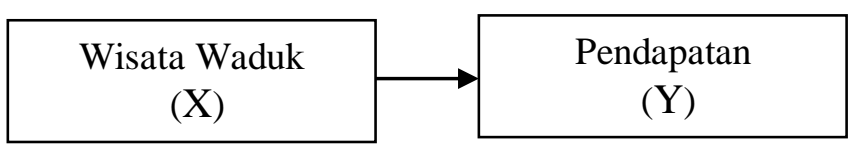

\section{Gambar 1}

\section{Kerangka Konseptual}

Dari gambar 1 di atas, peneliti akan melihat pengaruh kunjungan wisata Waduk Jeulikat terhadap pendapatan masyarakat disekitar tempat wisata.

\section{Hipotesis}

Penelitian ini akan membuktikan hipotesis sebagai berikut :

$\mathrm{H}_{1}$ : Diduga wisata Waduk Jeulikat berpengaruh positif dan siqnifikan terhadap pendapatan masyarakat di Kota Lhokseumawe .

\section{METODELOGI PENELITIAN}

\section{Objek dan Lokasi Penelitian}

Penelitian ini dilakukan di Waduk Jeulikat Kota Lhokseumawe. Adapun yang menjadi subjek dalam penelitian ini adalah pedagang di Wduk Jeulikat dengan objek yang di teliti yaitu pengaruh objek wisata Waduk terhadap pendapatan pedagang Desa Jeulikat Kecamatan Blang Mangat Kota Lhokseumawe.

\section{Populasi dan Sampel \\ Populasi}

Populasi merupakan keseluruhan obyek penelitian yang akan di teliti. Menurut (Sugiyono, 2008), adapun populasi dalam penelitian ini adalah seluruh pedagang di Waduk Jeulikat yang berjumlah 40 pedagang.

\section{Sampel}

Sampel adalah sebagian dari populasi yang ingin diteliti (Arikunto, 2006). Sedangkan menurut (Sugiyono,2004) sampel didefinisikan bagian dari jumlah yang dimiliki oleh populasi. Teknik pengambilan sampel dillakukan dengan metode sensus yaitu dengan cara mengumpulkan data dari populasi dengan mengambil seluruh anggota populasi. Jadi, sampel dalam penelitian ini adalah sebanyak 40 pedagang di Waduk. 


\section{Definisi Operasional Variabel}

Wisata waduk (X)

Merupakan daya tarik bagi pengunjung untuk datang menikmati tempat tersebut. Yang diukur dari jumlah pengeluaran pengunjung dalam satuan rupiah.

Pendapatan (Y)

Merupakan pendapatan pedagang beraktivitas dipersekitaran waduk yang diukur dengan satuan rupiah.

\section{Metode Analisis Data}

Untuk melakukan analisa data dalam penelitian ini peneliti menggunakan analisis kuantitatif. Data yang diperoleh dalam bentuk angka selanjutnya akan dianalisis dengan menggunakan bantuan peralatan statistik. Dalam hal ini penulis menggunakan model untuk melihat sejauh mana korelasi (hubungan) modal dan Upah terhadap jumlah tenaga kerja dengan menggunakan rumus regresi linier berganda. Dalam menganalisis data penelitian ini menggunakan metode teknik statistik deskriptif. Teknik ini digunakan untuk mengukur pengaruh masing-masing variabel terikat. Adapun persamaan regresi adalah sebagai berikut :

$$
\mathrm{Y}=\mathrm{a}+\beta \mathrm{X}+\mathrm{e}
$$

Dimana:

$$
\begin{array}{ll}
\mathrm{Y} & =\text { Pendapatan Masyarakat } \\
\mathrm{a} & =\text { Konstanta } \\
\mathrm{b} & =\text { Koefisien Regresi } \\
\mathrm{X} & =\text { Jumlah Pengunjung } \\
\mathrm{e} & =\text { error term }
\end{array}
$$

\section{HASIL PENELITIAN DAN PEMBAHASAN}

\section{Hasil Penelitian}

\section{Gambaran Umum Kota Lhokseumawe}

Kota lhokseumawe merupakan wilayah pemekaran dari kabupaten aceh utara yang terletak di pesisir timur pulau sumatera.Secara geografis wilayah kota lhokseumawe terletak di antara 4 - 5 lintang utara, 96 - 97 Bujur timur dan mempumyai luas wilayah 181,06 km yang sebagian besar lahan di gunakan untuk pemukiman penduuduk.

\section{Metode Analisis Data}

Untuk mengetahui hasil penelitian ini dapat dilihat dari output regresi liniear berganda yang memakai program EVIEWS 9 sebagai alat analisis pada tabel 2 berikut ini:

\section{Tabel 2}

\section{Hasil Analisis Linear Berganda}

Dependent Variable: LOG(Y)

Method: Least Squares

Sample: 140

Included observations: 40

\begin{tabular}{lrccc}
\hline \hline \multicolumn{1}{c}{ Variable } & Coefficient & Std. Error & t-Statistic & Prob. \\
\hline \multicolumn{1}{c}{ C } & 7.247976 & 1.172462 & 6.181842 & 0.0000 \\
\multicolumn{1}{c}{ LOG(X1) } & 1.113334 & 0.173799 & 6.405884 & 0.0000 \\
\hline \hline R-squared & 0.519202 & Mean dependent var & 14.74599 \\
Adjusted R- & & & \\
squared & 0.506550 & S.D. dependent var & 0.612240 \\
S.E. of regression & 0.430074 & Akaike info criterion & 1.198990 \\
Sum squared resid & 7.028631 & Schwarz criterion & 1.283434 \\
Log likelihood & -21.97979 & Hannan-Quinn criter. & 1.229522 \\
F-statistic & 41.03535 & Durbin-Watson stat & 1.882686 \\
Prob(F-statistic) & 0.000000 & & \\
\hline \hline
\end{tabular}

Sumber: Data Diolah (2018)

Dari Hasil perhitungan statistik melalui program Eviews hasilnya dapat dilihat pada tabel 2 di atas, maka perolehan persamaan hasil regresi sederhananya sebagai berikut:

$$
\mathrm{Y}=7,247976+1,113334
$$

Dari hasil persamaan regresi diatas menunjukkan nilai variabel kostanta mempunyai koefisien sebesar 7,247976 yang bearti jika variabel-variabel observasi jumlah pengunjung tidak ada atau dianggap tetap, maka pendapatan masyarakat waduk jeulekat akan mempunyai nilai sebesar Rp 7.247.976. Variabel pengunjung mempunyai koefisien regresi sebesar 1,113334 yang bearti bahwa apabila jumlah pengunjung bertambah sebanyak satu jiwa, maka pendapatan masyarakat waduk jeulekat akan meningkat $\mathrm{Rp}$ 1,113334 .

\section{Uji Asumsi Klasik Uji Normalitas}

Uji normalitas bertujuan untuk menguji apakah data yang digunakan dalam suatu model regresi linear mempunyai data yang distribusi normal ataupun tidak. Model regresi yang baik adalah memiliki distribusi data normal atau mendekati normalitas. Untuk melihat data sudah berdistribusi normal atau tidak maka dapat diuji 
menggunakan eviews sebagaimana yang ada pada gambar berikut:

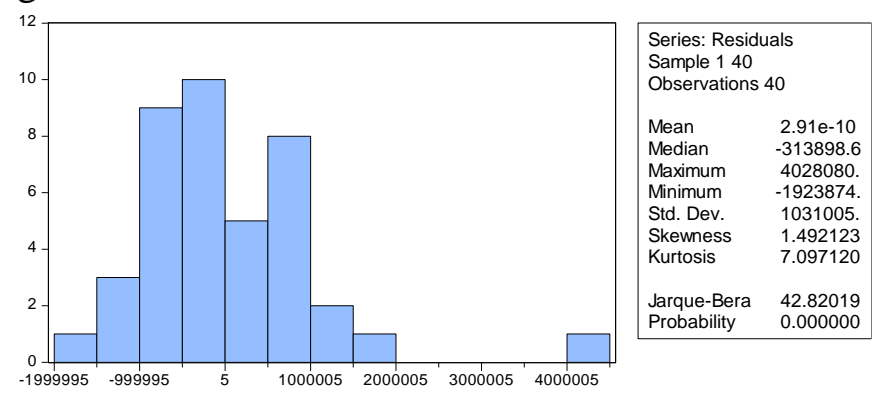

Sumber: Data Diolah (2018)

\section{Gambar 2}

\section{Hasil Uji Normalitas}

Dari gambar 2 di atas dapat dilihat bahwa grafik histrogram dapat membentuk pola distribusi simetris, dengan demikian maka dinyatakan residual terdistribusi normal. Untuk mendeteksi apakah residualnya berdistribusi normal atau tidak dengan membandingkan nilai Jarque Bera dengan $x^{2}$ (chi-suquare) tabel, yaitu sebagai berikut :

a. Jika nilai JB $>x^{2}$ (chi-square) tabel, maka residualnya berdistribusi tidak normal.

b. Jika nilai JB $<x^{2}$ (chi-square) tabel, maka residualnya berdistribusi normal.

Hasil dari uji normalitas pada gambar, bahwa nilai JB $(42.82)<x^{2}$ (chi-square) tabel (53.38) maka dapat disimpulkan bahwa residual berdistribusi normal.

\section{Uji Heteroskedastisitas}

Heteroskedastisitas adalah dimana keadaan varians dari setiap gangguan tidak konstan. Uji heteroskedastisitas dapat dilakukan dengan menggunakan uji White yang tersedia didalam program Eviews.

\section{Tabel 4}

\section{Hasil Uji Heteroskedastisitas}

Heteroskedasticity Test: White

\begin{tabular}{lll}
\hline \hline F-statistic & 29.43227 & Prob. F(2,37) \\
Obs*R-squared & 24.56155 & Prob. Chi-Square(2) \\
Scaled explained SS & 87.95471 & Prob. Chi-Square(2) \\
\hline
\end{tabular}

Sumber: Data Diolah (2018)

Untuk mendeteksi ada tidaknya heteroskedastisita maka dengan membandingkan nilai R-squared dan tabel $x^{2}$. a. Jika nilai Obs*R-squared $>x^{2}$ (chi-square) tabel, maka tidak lolos dari uji heteroskedastisitas.

b. Jika nilai Obs*R-squared $<x^{2}$ (chi-square) tabel, maka lolos dari uji heteroskedastisitas.

Dari hasi tabel di atas dapat dilihat bahwa nilai obs* R-square untuk hasil estimasi uji white adalah sebesar 24,56 dan nilai $x^{2}$ tabel dengan derajat kepercayaan 5\% dan df adalah 53.38 karena nilai Obs*R-squared $(24,56)<x^{2}$ (chi-square) tabel (53.38) maka dapat disimpulkan bahwa model diatas lolos dari heteroskedastisitas.

\section{Uji Statistik}

\section{Uji Parsial (Uji-t)}

Uji parsial digunakan untuk menguji apakah nilai koefesien regresi mempunyai pengaruh yang signifikan dan dilakukan berdasarkan perbandingan nilai $\mathrm{T}_{\text {hitung }}$ masing-masing koefesien regresi dengan nilai $\mathrm{T}_{\text {tabel }}$ dengan tingkat signifikan $5 \%$ dengan kebebasan $\mathrm{df}=(\mathrm{n}-\mathrm{k}-1)$.

\section{Tabel 4}

\section{Uji parsial (Uji t)}

\begin{tabular}{|c|c|c|c|c|c|}
\hline \multicolumn{6}{|c|}{ Variabel Dependen (Pendapatan) } \\
\hline Nama Variabel & t-statistik & t-tabel & Prob & Keterangan & Hipotesis \\
\hline X1 & 6,405 & 2.024 & 0,0000 & Signifikan & Diterima \\
\hline
\end{tabular}

Sumber: Hasil Penelitian (Data Diolah,2018)

Berdasarkan hasil pengujian sebagaimana yang telah ditunjukkan pada tabel di atas maka dapat dilihat bahwa jumlah pengunjung memiliki nilai thitung sebesar 6,405 dengan nilai signifikansi sebesar 0,0000 sementara nilai $t_{\text {tabel }}$ dengan $(\mathrm{df})=$ n-k $(40-1=39)$ pada $\alpha=0,05$ diperoleh nilai sebesar 2.024 maka $t_{\text {hitung }}>t_{\text {tabel, }}$ yaitu $6,405>$ 2.024 dengan niali siqnifikansi $<0,05$ maka keputusannya adalah menolak $\mathrm{H}_{0}$ dan menerima $\mathrm{H}_{\mathrm{a}}$, yang bearti bahwa secara parsial jumlah pengunjunh berpengaruh secara sigifikan terhadap pendapatan masyarakat waduk jeulekat.

0.0000
Determinasi 0 Ro
Koefisien Konolasi
Konelasi (R)

Untuk mengetahui tingkat korelasi ataupun hubungan antara variabel independen terhadap variabel dependen pada objek wisata waduk jeulekat dapat dilihat dari nilai $R$-Squared. Nilai $R$ Squared yaitu $\sqrt{R^{2}}=\sqrt{0,519202}=0,720556$ ini 
menunjukan bahwa hubungan jumlah pengunjung sangatlah kuat secara positif, karena nilai 0,793735 mendekati positif satu (+1). Dalam hal ini ketika nilai $R$-Squared memiliki hubungan yang sangat kuat berarti kondisi penelitian ini untuk menguji antara variabel independen terhadap variabel dependen sangatlah baik.

\section{Koefisien Determinasi $\left(\mathbf{R}^{\mathbf{2}}\right)$}

Dalam perhitungan statistik nilai $\mathrm{R}^{2}$ yang digunakan adalah adjusted R-squared. Adjusted R-squared adalah suatu indikator yang digunakan untuk mengetahui pengaruh penambahan suatu variabel independen ke dalam suatu persamaan regresi. Nilai adjusted $\mathrm{R}^{2}$ telah dibebaskan dari pengaruh derajat kebebasan (degree of fredom) yang berarti nilai tersebut telah benar-benar menunjukan bagaimana pengaruh variabel independen terhadap variabel dependen.

\section{Tabel 5}

Hasil Uji Adjusted R-squared

$$
\text { Adjusted R-squared }=0.506550
$$

Sumber : Hasil Penelitian (Data Diolah, 2018)

Berdasarkan tabel 5 di atas diketahui bahwa nilai koefisien determinasi $\left(\mathrm{R}^{2}\right)$ adalah sebesar $=0,5065$ atau $50,65 \%$, artinya pengaruh variabel jumlah pengunjung terhadap pendapatan masyarakat waduk adalah sebesar 0,50,65 atau $50,65 \%$ dan di pengaruhi oleh variabel lain yang tidak dimasukkan dalam model penelitian ini sebesar 0,4945 atau 49,45\%.

\section{Pembahasan}

\section{Pengaruh Jumlah pengunjung Terhadap Pendapatan Masyarakat Waduk Jeulekat}

Berdasarkan hasil pengujian bahwa jumlah pengunjung berpengaruh secara signifikan terhadap pendapatan masyarakat waduk jeulekat. Hal ini ditunjukan dengan nilai $t_{\text {hitungsebesar }}$ 6,405 dengan nilai signifikansi sebesar 0,0000 sementara nilai $\mathrm{t}_{\text {tabel }}$ dengan $(\mathrm{df})=\mathrm{n}-\mathrm{k}(40-1=39)$ pada $\alpha=0,05$ diperoleh nilai sebesar 2.024. Maka $t_{\text {hitung }}>t_{\text {tabel }}$, yaitu $6,405>2.024$. Apabila jumlah pengunjung meningkat sebesar 1 jiwa maka pendapatan masyarakat waduk jeulekat juga akan meningkat sebesar Rp 7.247.976
Hasil penelitian menunjukkan bahwa jumlah pengunjung berpengaruh positif terhadap pendapatan Masyarakat di kawasan Waduk Jeulikat. Adanya pengaruh positif disebabkan karena apabila banyaknya jumlah wisatawan yang mengunjungi obsek wisata khususnya wisata waduk jeulikat maka akan memberikan kontribusi bagi pedagang yang kesehariannya menjadi pedagang di kawasan wisata tersebut.

Semakin banyak jumlah pengunjung maka akan semakin besar pula pendapatan yang di hasilkan oleh pedagang. Jenis jajanan yang di perjual belikan pada umunya berupa makanan dan minuman. Peningkatan pariwisata dapat mempengaruhi perubahan struktur pendapatan terhadap masyarakat sekitar. Suatu objek wisata dapat meningkatkan pendapatan apabila jumlah wisatawan yang berkunjungpun banyak. Wisatawan yang berkunjung ke suatu tempat wisata pasti akan melakukan transaksi yang mengeluarkan sejumlah uang untuk dibelanjakan, sehingga menjadi pemasukan bagi mereka yang berjualan disekitar objek wisata tersebut.

Hasil penelitian ini sejalan dengan penelitian sebelumnya yang di lakukan oleh Yoto (2011), Sarah (2013), yud (2014) yang membuktikan bahwa keberadaan objek wisata berpengaruh terhadap pendapatan masyarakat. Hasil penelitian ini tidak sejalan dengan penelitian sebelumnya yang di lakukan oleh Selly (2017) yang membuktikan bahwa kunjungan wisata tidak berpengaruh terhadap pendapatan masyarakat.

\section{KESIMPULAN DAN SARAN Kesimpulan}

Berdasarkan hasil penelitian yang telah dilakukan, maka dapat disimpulkan bahwa: Secara parsial dapat disimpulkan bahwa variabel jumlah pengunjung berpengaruh secara signifikan terhadap pendapatan masyarakat waduk jaulekat.

\section{Saran}

Berdasarkan hasil penelitian dan kesimpulan di atas, maka penulis memberikan beberapa saran sebagai berikut :

1. Bagi Dinas Pariwisata, diharapkan wisata waduk jeulikat dapat di jadikan salah satu 
sumber tempat wisata yang mampu menarik minat para wisatawan sehingga akan membantu pembangunan ekonomi khususnya Lhokseumawe.

2. Bagi Pedagang, Untuk meningkatkan jenis penjualan yang di butuhkan oleh para wisatawan.

Bagi petugas Wisata, Untuk memberikan pelayanan yang memuaskan bagi pengunjung wisata waduk Jeulikat.

\section{DAFTAR PUSTAKA}

AAfifudin. (2016). Pengaruh lokasi, promosi dan harga terhadap kepuasan konsumen di wisata bahari lamongan. Jurnal Ilmu Dan Riset Manajemen, ISSN: 2461-0593, 5(12), $1-17$.

Afrida, BR. 2003. Ekonomi Sumber Daya Manusia. Jakarta. Ghalia Indonesia.

Anindita, M. 2015. Analisis Faktor-Faktor yang Mempengaruhi Tingkat. Kunjungan ke Kolam Renang Boja. Semarang: Fakultas Ekonomika dan. Bisnis Universitas Diponegoro.

Faisal, Sanapiah. (1999). Metode Penelitian Kuantitatif. Jakarta: Raja Grafindo Persada.

Gusneli. (2016). Pengaruh Fasilitas Wisata Terhadap Kepuasan Pengunjung ke Objek Wisata Air Terjun Bayang Sani Kabupaten Pesisir Selatan.

Hiariey, L. S., \& Sahusilawane, W. (2013). Dampak Pariwisata Terhadap Pendapatan Dan Tingkat Kesejahteraan Pelaku Usaha Di Kawasan Wisata Pantai Natsepa, Pulau Ambon. Jurnal Organisasi Dan Manajemen, Volume 9,(1), 87-105.

Ikatan Akuntansi Indonesia (IAI). 2011. Standar Profesional Akuntan Publik 31. Maret 2011.

Jaya, 2011. Kontribusi Wisata Bahari Terhadap Pendapatan. Rumah Tangga Nelayan Karangsong Kabupaten
Indramayu. Fakultas. Perikanan dan Ilmu Kelautan. Skripsi.

Mankiw, N. Gregory. 2006. Makro Ekonomi Edisi Keenam. Erlangga. Jakarta

Manurung, Mandala. 2008. Teori Ekonomi Makro. Edisi. Keempat : PT Gramedia Pustaka Utama. Jakarta.

Nazir, M. 2010. Metode Penelitian. Ghalia Indonesia, Bogor

Ridwan,Mohamad. (2012), Perencanaan dan Pengembangan Pariwisata. PT SOFMEDIA: Medan.

Reksoprayitno, S. (2004) Ekonomi Makro. Edisi Pertama. BPFE. UGM.Yogyakarta

Rosady, R. (2010). Metode Penelitian: Public Relations \& Komunikasi. Jakarta: Rajawali Pers.

Ratnasari, L. (2015). Analisis kualitas pelayanan terhadap kepuasan pengunjung lawang sewu. Pariwisata, 2, 1-14.

Rifaul Kirom, N., \& Wayan Jaman Adi Putra, I. (2016). Faktor-Faktor Penentu Daya Tarik Wisata Budaya dan Pengaruhnya terhadap Kepuasan Wisatawan. Jurnal Pendidikan: Teori, Penelitian, Dan Pengembangan, 1(3), 536-546.

Rosita, Marhanah, S., \& Wahadi, W. H. (2016). Pengunjung Di Taman Margasatwa the Influence of Tourism Facilities and Quality of Service To Customer Satisfaction At Taman Margasatwa. Manajemen Resort Dan Leisure, 13(1), 61-72. 